\title{
年齢・作業の難易度・文字の大きさ・背景色を考慮したディス プレイ設計*
}

\author{
森若 誠**, 村田厚生 $* *$, 河村征男 $* * *$
}

\section{1. 序 論}

自動車の運転中に空調の操作を行うなど二つの作業を 同時に行う行為はWickens $ら^{1,2)}$ のいう二重課題の状況 に該当する：二重課題の状況で作業をすると一方のみに 集中してしまい，もう一方がおろそかになってしまう危 険がある，自動車の運転作業の場合，スイッチ押し作業 に集中してしまい, 交通事故を引き起こす可能性もあ る.しかし, スイッチ押し作業の操作性を向上させるこ とで危険性を下げることができる. 自動車の操作性を向 上させる方法として，ステアリング・スイッチを導入し て操作時間を速くする方法 ${ }^{325)}$ とディスプレイの視認性 を上げて, 運転者の素早い反応を可能にする ${ }^{6 \sim 8)}$ という 二つの方法が考えられる.

ステアリング・スイッチは前方を見た状態で（視線移 動なしで）操作できるという利点をもっている．スイッ チの位置と作業効率について検討した研究3)では, ステ アリング・スイッチを用いることで運転者左前方にス イッチを置いたときよりもスイッチ押しに要した時間を 短くできたと報告している，単独作業における最適ス イッチ個数について検討した研究4)ではスイッチ個数を 13 個以上にすると操作時間が 11 個のときよりも大幅に 落ちるため, 13 個以上のスイッチは不適であるという 結果を報告している. ディスプレイの位置とスイッチ位 置とを組み合わせた効果について述べた研究5)では, ス テアリング・スイッチを用いる場合にはディスプレイの 位置を運転者の正面に置くのがよいと報告している.

ディスプレイの視認性を上げるにも様々な方法が存在 する ${ }^{6 \sim 8)}$. 文字の色や背景を変化させ, 視認性の高い組

* 受付 : 2005 年 5 月 23 日 受理：2006 年 1 月 19 日

** 岡山大学大学院 自然科学研究科

Graduate School of Natural Science and Technology

*** リコー中国株式会社

Ricoh Chugoku Co., Ltd.

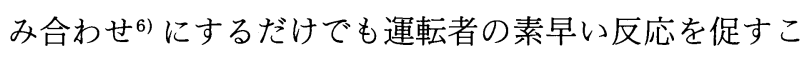
とができる. 文字の色や背景を変化させる以外にも視認 性を高める方法は検討されている. 文字に色調補正や エッジ強調を施したり7), 文字の大きさを変化させたり

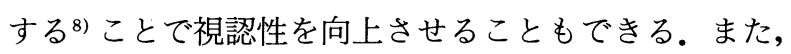
文字の大きさ, コントラストと年齢との関係について調 査した研究9)では, 文字を大きくする, コントラストを 上げることで高齢者でも若年者の作業時間に近い值で操 作できるということを示している. しかし, 高齢者の知 覚特性について考慮されていないため, すべての人間に 使いやすい設計を行っているとは言えない.

高齢者の知覚特性についての研究が行われており, 高 齢者は色刺激に対する反応時間が遅く，また色刺激間で の反応のばらつきが若年者よりも大きいことが示されて いる ${ }^{10)}$. 事象関連脳電位 P 300 を用いて若年者と高齢者 の色刺激に対する認知時間について検証した研究 ${ }^{11)}$ は, 赤色刺激条件では若年者と高齢者の間に認知時間の 差が見られなかったが, 青色刺激では高齢者のほうが若 年者よりも認知時間が有意に長くなったと報告してい る.しかし, これらの研究は高齢者に対する一般的な知 覚特性を見てきたもので，自動車のディスプレイ設計に おいて参考になるような高齢者知覚特性について考慮さ れていない.

そこで本研究では, スイッチ位置, スイッチの使用個 数, 配置方法を固定し，作業の難易度，画面内に表示さ れる文字の大きさおよび背景色がディスプレイの使いや すさにいかに影響するかに関して, 若年者と高齢者で比 較を試みた. 文字の大きさは MS ゴシックで $14 \mathrm{pt}$. と 21 pt.の 2 種類, 背景色は色の波長が両極端なものであ る赤と青の 2 種類とし, 課題難易度 (本研究では難と易 の 2 水準を設定）によって使いやすいデザインが異なる かどうかを検証するために，それぞれを組み合わせた計 8 条件で実験を行った。被験者にはトラッキング作業を 行いながら，画面上に提示された課題をステアリング・ 
スイッチによって操作する二重課題を課し，作業時間， 操作性の心理評価等の観点から使いやすいディスプレイ 設計について検討した。

\section{2. 実験方法}

\section{2-1. 被験者}

被験者は健常な若年者（21～23歳）10名，高齢者 （65～73 歳）10 名とした. また被験者は全員運転免許証 を所持しており, 視力の悪い者には眼鏡・コンタクトレ ンズの着用を義務付けた。

\section{2-2． 実験装置}

トラッキング作業のための追従刺激の提示およびステ アリングによるカーソル制御を行うためにパソコン （HITACHI 製 FLORA 450）とロータリーエンコーダ (OMRON 製 $\mathrm{E} 6 \mathrm{~F}-\mathrm{AB} 3 \mathrm{C})$ とデジタル I/O ボード

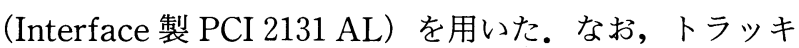
ング作業の画面はプロジェクター（PLUS 製 V-1080） を用いて被験者の前方に設置してあるスクリーンに投影 した。また，スイッチ押し作業の実験画面の表示および 実験課題の提示に TFTLCD ララーディスプレイ (SONY 製 SDM-N 50)，ノートパソコン（SOTEC 製 e-noteH 370 TDX 4), デジタル I/O カード（CONTEC 製 PIO-24 W (PM)) を用いた。これらの機器を図 1 に 示すような形に配置し実験を実施した。なお，実験室内 の照度についてはある程度の調整を行い, ほぼ一定の照 度になるようにした（スクリーン中央付近：18.3 lx, ディスプレイ中央付近：25.2 lx，スイッチ周辺：15.3 lx (すべて鉛直方向で測定)).

課題遂行に用いたスイッチは 1 〜 5 だの数字が書か

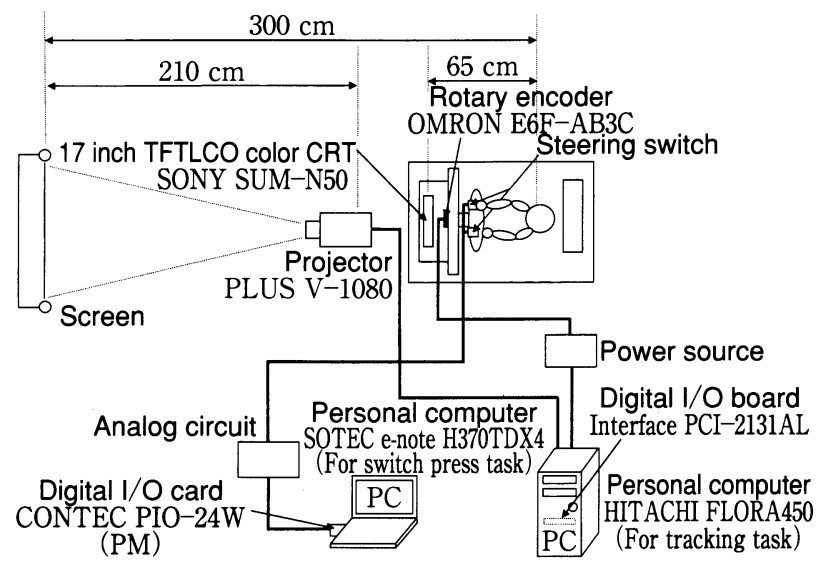

図 1 実験機器配置の概要

Fig. 1 Outline of arrangement of expeimental apparatus.
れたキーと十字型に配置された方向キーを組み合わせた もの5)とした.これらのスイッチをステアリング・ス イッチとして使用し，それぞれ左右の親指で押すことの 可能な領域にボタンを設置した。

\section{2-3. 作業内容}

\section{2-3-1. トラッキング作業}

この作業は主作業として実験を行った。この作業では 画面内に点線で示されるターゲットと画面下部に示され ている操作部の中心とを追従させるという課題を被験者 に課し，どれだけ正確に追従できるかを調査した。操作 部は被験者の正面に設置してあるハンドルと対応してお り，ハンドルを右に回すと回した量に比例して操作部が 右に移動するというような仕組みになっている。ター ゲットの位置は Watson らの方法 ${ }^{12)}$ に従って，6 個の異 なる位相および周波数をもつ $\sin$ 関数の和とした。ま た，ハンドルの位置と自動車の方向の変化率の関係は一 次遅れ系が一般であると述べられている11. 。こで本実 験の制御系は一次遅れ系とした。

\section{2-3-2. スイッチ押し作業}

この作業は副次作業として実験を行った。スイッチ押 し作業で用いた実験画面を図 2 に示す。(a)は難易度が低 い場合 (易課題)，(b)は難易度が高い場合（難課題）に 用いた実験画面である. 易課題, 難課題ともに画面上部 （課題提示部）に示された課題をステアリング・スイッ チを用いて操作する作業を課した。易課題の場合は「八 ザードをつけてください」のようにスイッチを 1 回押す ことで操作を終えることのできる課題を提示し, 難課題 の場合は「暖房をつけ温度を 26 度にしてください」の ように課題を終えるまでにスイッチを複数回押さなけれ ばならない課題を提示した。例で挙げた課題の場合, 空 調 $\rightarrow($ 暖房 $\rightarrow)$ 温度 $\rightarrow 26$ 度 $\rightarrow$ 決定の順で操作を行うため, 最低 4 回のスイッチ押し動作が必要になる（初期設定は 暖房 25 度の状態)。本実験では難課題における 1 課題あ たりの平均スイッチ押し数を 8.2 回（164 回/20 課題） にして実験を行った。被験者には易課題のみで構成され た課題もしくは難課題のみで構成された課題の両方を行 わせ，作業条件間で成績に差が見られるかを調査した。 1 作業に行う課題数は易課題, 難課題ともに 20 課題と し，課題の提示順序はランダムとした．また，背景色の 輝度は赤背景 $1.93 \mathrm{~cd} / \mathrm{m}^{2}$, 青背景 $1.57 \mathrm{~cd} / \mathrm{m}^{2}$ とした。

\section{2-4. 実験手順}

被験者を運転シートに座らせ，自分の操作しやすいよ うに座席の位置および高さを調節させた．実験開始前に 


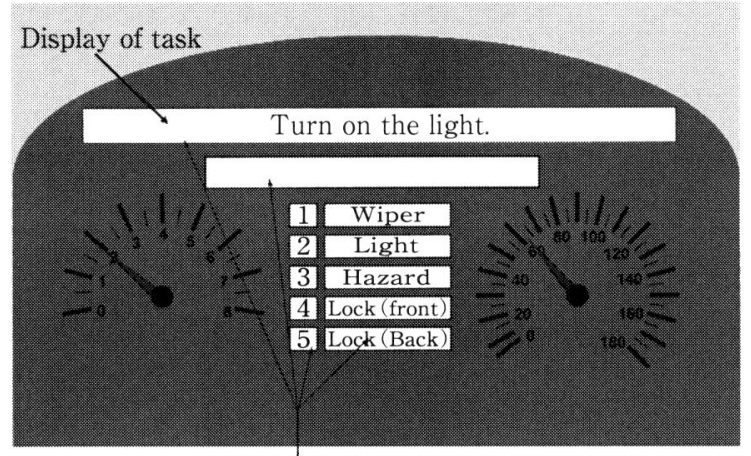

Background color : Blue or Red Character color : White

(a) 易課題

(a) easy task.

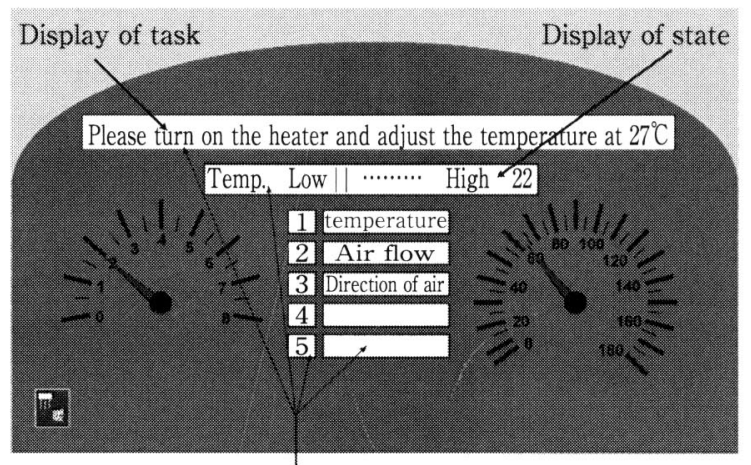

Background color : Blue or Red Character color : White

(b) 難課題

(b) difficult task.

図 2 スイッチ押し作業画面

Fig. 2 Displa of switch pressing task.

本実験で行う内容を説明し，スイッチ押し作業，トラッ キング作業の練習を行わせた，練習では実験で行う課題 を実際に行わせ，作業時間がほぼ一定になった時点で練 習を終了させた。実験はトラッキング作業を行いながら 画面上に示された課題をステアリング・スイッチを用い て操作する作業の二重課題とした．実験条件として背景 色 2 種類 (赤 or 青), 文字の大きさ 2 種類 (大 $(21$ pt.) or 小 (14 pt.)), 課題難易度 2 種類 (易課題 or 難 課題）の 3 条件を用意し，それぞれを組み合わせた 8 条 件を被験者に課した.なお，課題の順序は被験者ごとに ランダマイズした。1 条件が終了するごとに被験者には 主観評価に答えてもらい, 休憩をはさんで次の課題を実 施した。

\section{2-5。評価項目}

\section{2-5-1. 正答率}

スイッチ押し作業において提示された課題を正確に行 うことができた確率である. 正答した数を 1 作業の課題 数（20 課題）で割った值に相当する.

\section{2-5-2. 平均作業時間}

1 課題に要した平均時間を示す. 1 作業 20 課題に要し た時間（ただし，正答していないものは要した時間のな かに含まない）を正答数で割った值に相当する。

\section{2-5-3. トラッキング成績}

1 作業が終わるまでのトラッキング作業の成績を示し たものである.トラッキング成績の評価は，ターグット と操作部の中心との画面上での誤差（ピクセル）を被験 者が操作しているハンドルの角度に変換したもの (degree) とした. 50 回/秒の割合でターゲットと操作 部の中心との誤差を計測し, 作業が終了した時点での誤 差の平均值をトラッキング成績とした。トラッキング成 績の值が高いほど正確なハンドル操作ができなかったと いうことを示している.

\section{2-5-4。主観評価}

実験条件ごとに操作しやすかったかどうかについて調 查した. 評点は 7 段階になっており, 評点が高いほど操 作しやすかったことを示している.

\section{3. 実験結果}

図 3 にトラッキング成績, 図 4 に正答率, 図 5 に平均 作業時間, 図 6 に主観評価の結果をそれぞれ示す。各図 の横軸に表記されている $\mathrm{R}(\mathrm{L}), \mathrm{R}(\mathrm{S}), \mathrm{B}(\mathrm{L}), \mathrm{B}(\mathrm{S})$ は 背景色と文字の大きさの組み合わせを示したものであ る. $\mathrm{R}$ と表記されているものは背景色が赤の条件， B と 表記されているものは背景色が青の条件，（L）と表記さ れているものは提示された文字が大きい条件，（S）と表 記されているものは提示された文字が小さい条件をそれ ぞれ示している。

トラッキング成績については，若年者と高齢者に差は 見られたものの, 背景色および文字の大きさによる影響 はほとんど確認されなかった。 易課題, 難課題の結果に それぞれ背景色, 文字の大きさ, 年齢を要因とする 3 要 因の分散分析を実施した結果, 易課題, 難課題ともに年 齢条件においてのみ有意差が確認された（易課題：F $(1,18)=8.957, \quad p<0.01$, 難課題: $F(1,18)=20.183$, $p<0.01)$. 正答率の結果については, 易課題で実施し た場合には年齢, 背景色, 文字の大きさによる影響は確 認されなかったが, 難課題で実施した場合には年齢によ る影響が確認された。易課題, 難課題の結果にそれぞれ 背景色, 文字の大きさ, 年齢を要因とする 3 要因の分散 分析を実施した結果，難課題における年齢条件にのみ有 意差が確認された $(F(1,18)=6.569, p<0.05)$. 平均 作業時間の結果については, 易課題, 難課題ともに年噛 


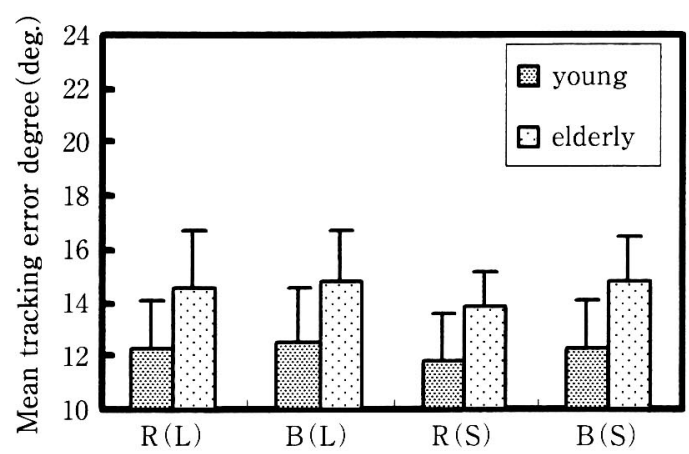

(a) 易課題

(a) easy task.

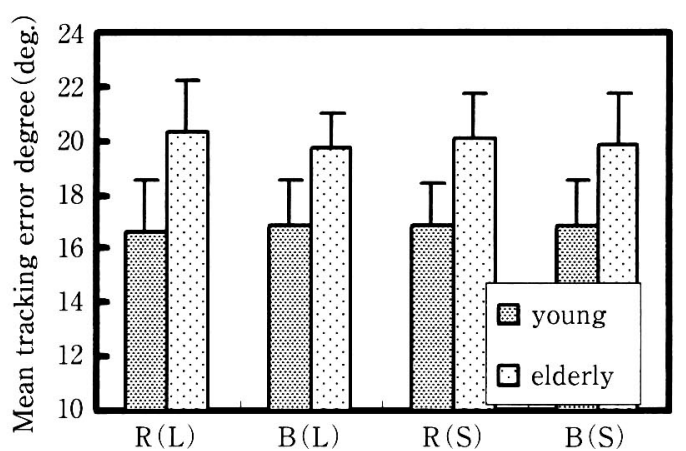

(b) 難課題

(b) difficult task.

図 3 年齢, 文字の大きさ, 背景色での平均トラッキング誤差の比較

Fig. 3 Tracking error as a function of age, character size and background color.

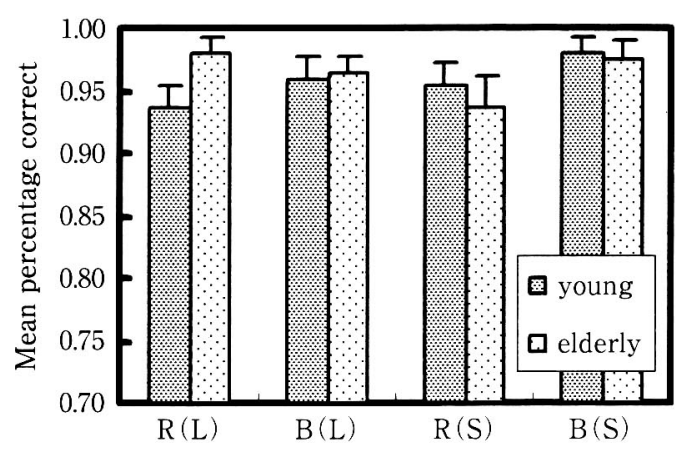

(a) 易課題

(a) easy task.

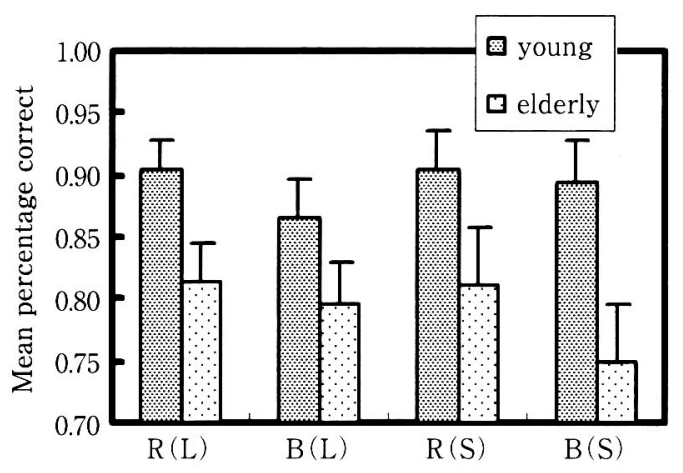

(b) 難課題

(b) difficult task.

図 4 年齢, 文字の大きさ, 背景色での平均正答率の比較

Fig. 4 Percentage correct as a function of age, character size and background color.

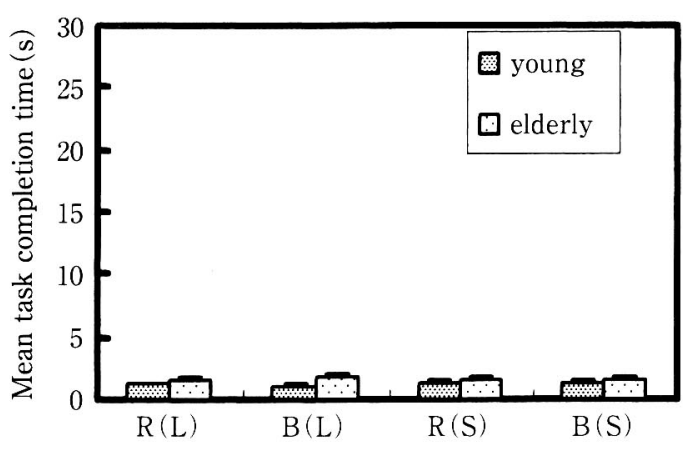

(a) 易課題

(a) easy task

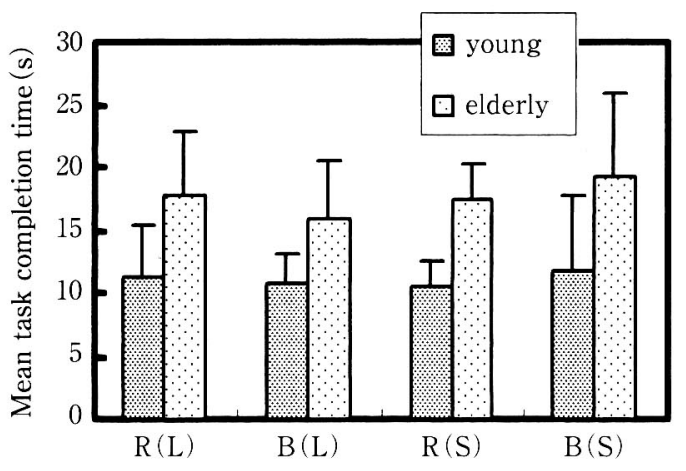

(b) 難課題

(b) difficult task.

図 5 年齢, 文字の大きさ, 背景色での平均作業時間の比較

Fig. 5 Mean task completion time as a function of age, character size and background color.

による影響は見られたが, 背景色, 文字の大きさの効果 についてはほとんど差が確認されなかった。易課題, 難 課題の結果にそれぞれ背景色, 文字の大きさ, 年齢を要 因とする 3 要因の分散分析を実施した結果, 易課題, 難 課題ともに年齢条件において有意差が確認された（易課 題: $F(1,18)=12.969, \quad p<0.01$, 難課題: $F(1,18)=$
$16.474, p<0.01)$. 主観評価の結果については年齢差が 大きく現れており，年齢差を要因とするMann-WhitneyのU 検定を行った結果, 難課題においては有意な 傾向がはっきりと現れており，易課題においても有意差 が確認された (易課題： $p<0.05$, 難課題 : $p<0.01$ ). しかし, 実験条件間についてはほとんど差がなく, 


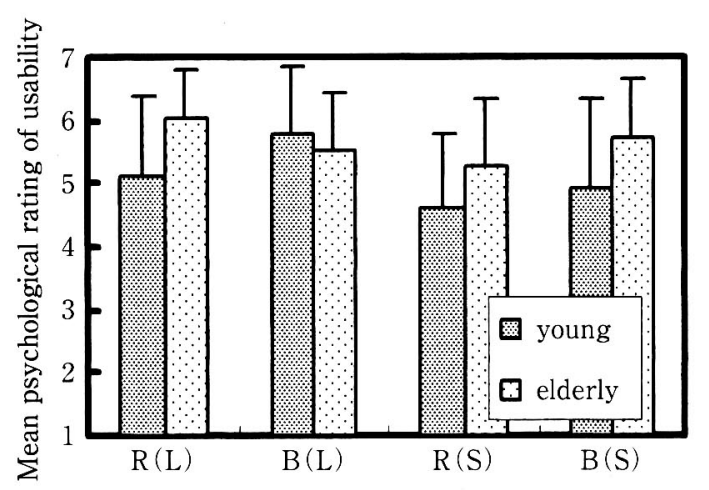

(a) 易課題

(a) easy task.

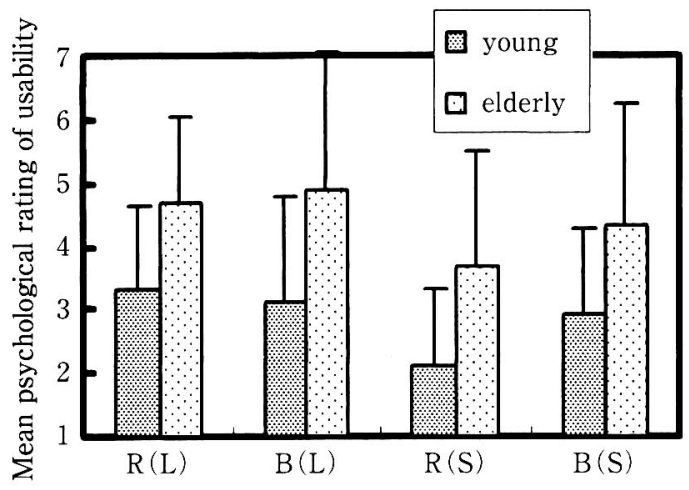

(b) 難課題

(b) difficult task.

図 6 年齢, 文字の大きさ, 背景色での操作性の主観評価の比較

Fig. 6 Mean psychological rating of usability as a function of character size and background color.

Kruskal-Wallis の検定を実施しても易課題, 難課題と もに有意差を確認することはできなかった。

\section{4. 考 察}

トラッキング成績については年齢以外の実験要因に有 意差を確認できなかったことより，トラッキング成績は 被験者の運動能力が影響するものであって, 画面の配色 や文字の大きさはトラッキング誤差にほとんど影響しな いということが示された (図 3 参照).このことは, Stelmach ら ${ }^{13)}$ の指摘したような高齢者の知覚・認知・ 運動機能の低下を明確に反映していると考えられる。ま た, 図 3 より, スイッチ押し作業の難易度が高くなるに つれて, 若年者と高齢者のトラッキング誤差の差が大き くなったことがわかる。これは, 認知的負荷が大きくな るにつれて, 知覚・認知・運動機能が低下した高齢者へ の影響が顕著になったことを示唆しているものと判断さ れる.

正答率については易課題では年齢, 背景色, 文字の大 きさによる差が見られなかったのに対し, 難課題では年 齢要因に有意差を確認できたことより，作業が複雑にな ると特に高齢者は正確な操作ができない可能性が高くな るということが示された (図 4 参照)。また, 難課題に なるほど, 高齢者と若年者の正答率の差が大きくなっ た。この結果は, 難易度が高くなり認知的負荷が増す と, Smith ら ${ }^{14)}$ のいうような高齢者の認知的能力, 特 に短期記憶能力の低下が影著に現れたことを示唆するの ではないかと判断できる。

平均作業時間については, 易課題, 難課題ともに年齢 による有意差のみが確認された。ただし難課題では, 赤 背景を用いた場合には文字の大きさと作業時間との間に 差はほとんど見られなかったが, 青背景を用いた場合に
は文字の大きさによる影響が大きく現れた (図 5 参照). すなわち, 文字が小さい場合には平均作業時間が赤背景 を用いた場合より遅くなったが, 文字が大きい場合には 平均作業時間が赤背景を用いた場合よりも速くなる傾向 が認められた。ただし，高齢者の難課題のみを対象に， 青背景で文字の大きさを要因とする 1 要因の分散分析を 実施した結果, 有意差が見られなかった $(F(1,9)=$ $0.679, p=0.43)$. 現段階では高齢者に扔ける難課題, 青背景に抢ける文字の大きさの影響を断言できない. Imbeau ら ${ }^{9}$ では, 作業の難易度については考慮されて いないが, 表示色の作業成績への影響を確認している. これは本研究結果と異なっているため, 今後さらに詳細 に背景色の影響についても検討していく必要がある.ま た, 作業課題が難しくなる活ど若年者と高齢者の作業時 間の差が大きくなった。これも, トラッキング誤差, 正 答率の結果と同様に, 高齢者の認知能力の低下 ${ }^{14)}$ が顕 著に現れたためではないかと推察される。

被験者による主観評価の結果では, 易課題では若年者 における青背景で文字が大きい場合の評価がよく, 難課 題では高齢者における赤背景で文字が小さい場合の評価 が悪くなっていることが確認された (図 6 参照)。平均 作業時間と主観評価の結果から, 文字が小さい条件は高 齢者にとっては見づらいものであるため避けるべきであ るということが示された。また, 本研究の範囲内では背 景色の影響に関しては赤（高波長）と青（短波長）で顕 著な差はなかった。

主作業と副次作業の注意の配分比率を調査するため, 副次作業の作業時間を横軸, 主作業のトラッキング誤差 を縱軸にとり，年齢および課題難易度の要因でそれぞれ 回帰直線を求めた（図 7 参照（実際のデー夕に応じて, 易課題は 5 秒まで, 難課題は 30 秒まで表示)). その結 果, 若年者, 高齢者ともに, 易課題では作業時間/卜 


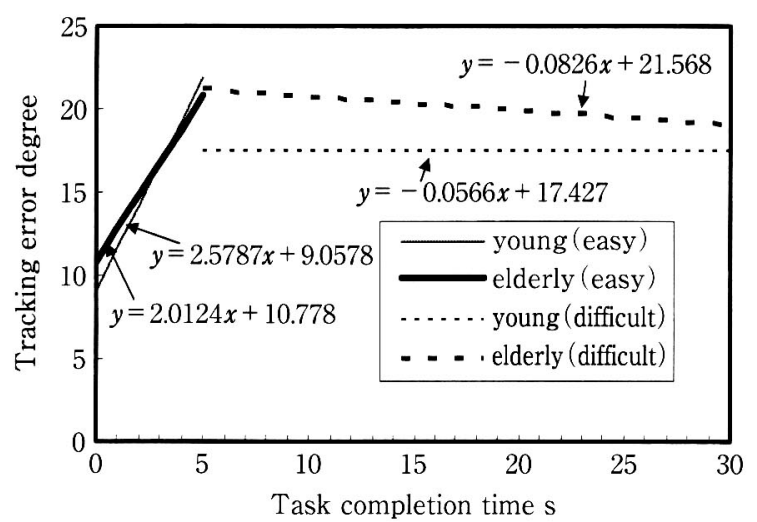

図 7 主作業と副次作業の注意の配分比率の違いを確認する ための作業時間とトラッキング誤差の関係

Fig. 7 Relation between task completion time and tracking error for easy and difficult conditions. This figure shows that the degree of allocation of attention to the secondary task becomes larger as the secondary task becomes difficult.

ラッキング誤差の值が小さくなっているのに対し, 難課 題では平均作業時間/トラッキング誤差の值がかなり大 きくなっていることが確認された，難課題では，両年齢 群ともに, トラッキング誤差はほぼ一定で作業時間がか なりばらつく傾向が認められた. 難課題では, 両年齢群 ともに, 易課題での同一のトラッキング䛊差に対する作 業時間は, 易課題の場合よりも大きくなっていた，以上 のことより, 難課題では副次作業への注意の配分比率が 大きくなっていることが示唆された.

以上の結果を総合的に判断して，特に高齢者に対して は本研究の難課題として設定した 3 層構造になっている ような運転中のスイッチ操作作業および自動車用の情報 表示として $14 \mathrm{pt}$. 程度の小さいサイズの文字は適切では ないということが示唆された. しかし, 背景色の影響に ついてはまだ断言できないため, より詳細な調査を行わ なければならない. また, 本実験では背景色 2 種類, 文 字の大きさ 2 種類で実験を行ったが, その他の背景色や 文字の大きさを使用しどのような結果が得られるかどう かを検証していく必要がある。

\section{5. 結 論}

本研究では, 仮想運転環境において, 副次課題の難易 度および表示情報の背景色と文字の大きさが作業成績に いかなる影響を及ぼすかを，年齢も実験要因として検討 した。その結果, 以下に示すような結論が得られた。

・トラッキング誤差, 正答率, 作業時間の比較結果か ら，高齢者に対しては，本実験の難課題で設定したよ うな多層の構造を有するような運転副次作業は望まし
くない. 易課題で設定したような単層の副次課題にす べきである。

・背景色および文字の大きさはトラッキング䛊差, 正答 率および平均作業時間にほとんど影響しないというこ とが示された.

・主観評価および作業時間の結果から文字が小さい場合 の成績が悪かったことより, 文字が小さい条件（本実 験では 14 pt.）は表示としては適切ではないことが再 確認された。

-本実験の範囲では, 背景色 (赤背景と青背景) の作業 成績への明確な影響は同定されなかったが, 今後さら に詳しく検討していく必要がある.

謝辞 本研究を遂行するに当たり多方面でご尽力を 賜った豊田合成(侏)開発部・感性工学 $\mathrm{G}$ の永田雅典氏に 深勘なる謝意を表する。なお, 本研究の一部は文部科学 省特定領域研究（770）「障害者・高柃者のコミュニケー ション機能に関する基礎的研究」の援助の下で行われ た。

\section{参考文献}

1) C. D. Wickens, S. E. Gordon \& Y. Liu: Human factors engineering, 259 279, Longman, 1998.

2) C. D. Wickens, D. L. Sandry \& M. Vidulich : Compatibility and resource competition between modalities of input, central processing, and output, human factors, 25(2), 227〜248, 1983.

3）永田雅典, 林 幸絵, 久保千穂, 安井真由美 : 自動車運 転中のスイッチ操作に関する一考察, 日本人間工学会東 海支部 2001 年度研究会論文集, 48～49, 2001.

4）佐橋祐哉, 江村陽平, 福田康明, 池村澄男：ステアリン グホイールスイッチの操作性に関する研究，日本人間工 学会東海支部 2001 年度研究会論文集, 46〜 47, 2001.

5）森若 誠, 村田厚生：ディスプレイとコントロールの 設置位置を考慮したステアリング・スイッチの有効性, 人間工学, $40(1), 12 \sim 20,2004$.

6) W. O. Galitz: The essential guide to user interface design, 486 520, John Wiley \& Sons, Inc., Toronto, 1997.

7）坂口靖雄, 樋口和則, 中野倫明, 山本 新: 目の順応特 性を考慮した車載ディスプレイの表示, 豊田中央研究所 R \& Bレビュー, 33(2), 37〜 45, 1998.

8）水野守倫, 桶口和則, 杉山和彦, 中野倫明, 山本 新 : 視 覚特性に基ブくディスプレイ表示法の開発, 豊田中央研 究所 R \& Bレビュー, 33(3), 77〜84, 1998.

9) D. Imbeau, W. W. Wierwille \& Y. Beauchamp : Age, display design and driving performance, B. Peacock \& W. Karwowski (eds.), Automotive ergonomics, 339 355, Taylor \& Francis, 1993.

10）鈴木敬明, 易 強, 櫻川智史, 田村久恵, 岡嶋克典：高 
齢者と若年者の色視認性評価と高齢者水晶体模擬フィル 夕の効果, 2002 年映像情報メディア学会要旨集 CD, 2002.

11）鈴木敬明, 易 強, 櫻川智史, 田村久恵, 岡嶋克典：色 刺激に対する認知時間の加齢変化一事象関連脳電位 P 300 による評価一, 日本照明学会第 36 回全国大会講演 集, 125, 2003.

12) R. W. Watson, R D. Jones \& N. B. Sharman: Twodimensional tracking tasks for quantification of sensory-motor dysfunction and their application to
Parkinson's disease, Medical \& Biological Engineering \& Computing, 23 (3), 141 144, 1997.

13) G. E. Stelmach \& A. Nahom: The effects of age on driving skill cognitive-motor capabilities, B. Peacock \& W. Karwowski (eds.), Automotive ergonomics, 219 233, Taylor \& Francis, 1993.

14) D. B. D. Smith, N. Mashkati \& M. M. Robertson : The older driver and passenger, B. Peacock \& W. Karwowski (eds.), Automotive ergonomics, 453 467, Taylor \& Francis, 1993. 